\title{
In vitro exposure to isoprene-derived secondary organic aerosol by direct deposition and its effects on $C O X-2$ and $I L-8$ gene expression
}

\author{
Maiko Arashiro ${ }^{1}$, Ying-Hsuan Lin ${ }^{1,6}$, Kenneth G. Sexton ${ }^{1}$, Zhenfa Zhang ${ }^{1}$, Ilona Jaspers ${ }^{1,2,3,4,5}$, Rebecca C. Fry ${ }^{1,3}$, \\ William G. Vizuete $^{1}$, Avram Gold ${ }^{1}$, and Jason D. Surratt ${ }^{1}$ \\ ${ }^{1}$ Department of Environmental Sciences and Engineering, Gillings School of Global Public Health, \\ University of North Carolina at Chapel Hill, Chapel Hill, NC 27599, USA \\ ${ }^{2}$ Center for Environmental Medicine, Asthma, and Lung Biology, School of Medicine, University of North Carolina \\ at Chapel Hill, Chapel Hill, NC 27599, USA \\ ${ }^{3}$ Curriculum in Toxicology, University of North Carolina at Chapel Hill, Chapel Hill, NC 27599, USA \\ ${ }^{4}$ Department of Pediatrics, School of Medicine, University of North Carolina at Chapel Hill, Chapel Hill, NC 27599, USA \\ ${ }^{5}$ Department of Microbiology and Immunology, School of Medicine, University of North Carolina at Chapel Hill, \\ Chapel Hill, NC 27599, USA \\ ${ }^{6}$ Michigan Society of Fellows, Department of Chemistry, University of Michigan, Ann Arbor, MI 48109, USA
}

Correspondence to: Jason D. Surratt (surratt@unc.edu)

Received: 13 May 2016 - Published in Atmos. Chem. Phys. Discuss.: 17 May 2016

Revised: 4 October 2016 - Accepted: 18 October 2016 - Published: 15 November 2016

\begin{abstract}
Atmospheric oxidation of isoprene, the most abundant non-methane hydrocarbon emitted into Earth's atmosphere primarily from terrestrial vegetation, is now recognized as a major contributor to the global secondary organic aerosol (SOA) burden. Anthropogenic pollutants significantly enhance isoprene SOA formation through acidcatalyzed heterogeneous chemistry of epoxide products. Since isoprene SOA formation as a source of fine aerosol is a relatively recent discovery, research is lacking on evaluating its potential adverse effects on human health. The objective of this study was to examine the effect of isoprenederived SOA on inflammation-associated gene expression in human lung cells using a direct deposition exposure method. We assessed altered expression of inflammationrelated genes in human bronchial epithelial cells (BEAS2B) exposed to isoprene-derived SOA generated in an outdoor chamber facility. Measurements of gene expression of known inflammatory biomarkers interleukin 8 (IL-8) and cyclooxygenase $2(C O X-2)$ in exposed cells, together with complementary chemical measurements, showed that a dose of $0.067 \mu \mathrm{g} \mathrm{cm}^{-2}$ of SOA from isoprene photooxidation leads to statistically significant increases in $I L-8$ and $C O X$ 2 mRNA levels. Resuspension exposures using aerosol filter extracts corroborated these findings, supporting the conclu-
\end{abstract}

sion that isoprene-derived SOA constituents induce the observed changes in mRNA levels. The present study is an attempt to examine the early biological responses of isoprene SOA exposure in human lung cells.

\section{Introduction}

Recent work has shown that isoprene (2-methyl-1,3butadiene) is an important precursor of secondary organic aerosol (SOA), which has potential impacts on climate change and public health (Lin et al., 2013b, 2016; Rohr, 2013). Current understanding of isoprene SOA formation is based on laboratory studies showing that gasphase photooxidation of isoprene generates key SOA precursors, including isomeric isoprene epoxydiols (IEPOX), methacrylic acid epoxide (MAE), hydroxymethyl-methyl$\alpha$-lactone (HMML), and isoprene hydroxyhydroperoxides (ISOPOOH) (Paulot et al., 2009; Surratt et al., 2010; Lin et al., 2012, 2013b; Nguyen et al., 2015; Krechmer et al., 2015; Liu et al., 2016; Riva et al., 2016). The formation of SOA from these precursors is influenced by controllable anthropogenic emissions such as oxides of nitrogen $\left(\mathrm{NO}_{x}\right)$ and sulfur dioxide $\left(\mathrm{SO}_{2}\right)$. Atmospheric oxidation of $\mathrm{SO}_{2}$ contributes 
to particle acidity, which enhances isoprene SOA formation through acid-catalyzed reactive uptake and multiphase chemistry of IEPOX and MAE (Surratt et al., 2007, 2010; Lin et al., 2012; Gaston et al., 2014; Riedel et al., 2015), while $\mathrm{NO}_{x}$ determines whether the oxidation pathway leading to IEPOX or MAE/HMML predominates (Lin et al., 2013b; Surratt et al., 2010; Nguyen et al., 2015). Isoprene SOA comprises a large portion of global atmospheric fine particles $\left(\mathrm{PM}_{2.5}\right.$, aerosol with aerodynamic diameters $\leq 2.5 \mu \mathrm{m}$ ) (Carlton et al., 2009; Henze et al., 2008), but few studies have focused on its health implications (Lin et al., 2016). Evaluating the health effects of SOA from isoprene oxidation is important from a public health perspective, not only because of its atmospheric abundance but also because the anthropogenic contribution is the only component amenable to control (Pye et al., 2013; Gaston et al., 2014; Xu et al., 2015; Riedel et al., 2015).

Many studies have shown that particulate matter is closely linked to health effects ranging from exacerbation of asthma symptoms to mortality associated with lung cancer and cardiopulmonary disease (Dockery et al., 1993; Schwartz et al., 1993; Samet et al., 2000). $\mathrm{PM}_{2.5}$, in particular, has been linked to negative health outcomes with an estimated contribution of 3.2 million premature deaths worldwide as reported in the Global Burden of Disease Study 2010 (Lim et al., 2012). Despite evidence that particle composition affects toxicity, fewer studies focus on the link between chemical composition and health/biological outcomes (Kelly and Fussell, 2012). Prior work on complex air mixtures has shown that gaseous volatile organic compounds (VOCs) alter the composition and ultimately the toxicity of particles (Ebersviller et al., 2012a, b). SOA resulting from natural and anthropogenic gaseous precursors, such as $\alpha$-pinene and 1,3,5-trimethylbenzene, has been shown to affect cellular function (Gaschen et al., 2010; Jang et al., 2006) and recently isoprene SOA formed from the reactive uptake of epoxides has been shown to induce the expression of oxidative stress genes (Lin et al., 2016).

The objective of this study is to generate atmospherically relevant isoprene-derived SOA and examine its toxicity through in vitro exposures using a direct deposition device. Compared to exposure of cells in culture media to resuspended particles, direct particle deposition likely provides a more biologically relevant exposure model and enhances sensitivity of cells to air pollution particle exposures (Volckens et al., 2009; Lichtveld et al., 2012; Hawley et al., 2014a, b; Zavala et al., 2014; Hawley and Volckens, 2013). The Electrostatic Aerosol in Vitro Exposure System (EAVES) used in this study deposits particles, generated in our outdoor photochemical chamber, directly onto lung cells by electrostatic precipitation (de Bruijne et al., 2009). Similar techniques and devices have been used to expose cells to diesel exhaust particles (Lichtveld et al., 2012; Hawley et al., 2014b), but our study is the first to utilize the EAVES to explore the potential adverse effects of isoprene SOA on human lung cells. Additionally, for a more atmospherically relevant exposure, isoprene SOA was photochemically generated in an outdoor chamber to mimic its formation in the atmosphere.

We have recently demonstrated through a chemical assay that isoprene-derived SOA has the potential for inducing reactive oxygen species (ROS) (Kramer et al., 2016), which are linked to oxidative stress and inflammation (Reuter et al., 2010; Li et al., 2003). An in vitro study that followed supported the potential for isoprene SOA to affect the levels of oxidative stress genes (Lin et al., 2016). In this study we chose to examine the gene expression levels of interleukin$8(I L-8)$ and cyclooxygenase-2 (COX-2), not only for their links to inflammation and oxidative stress (Kunkel et al., 1991; Uchida, 2008) but also because both have been examined in previous studies using the EAVES for fresh and aged diesel exhaust (Lichtveld et al., 2012). Other studies on air pollution mixtures have also examined $I L-8$ as a biological endpoint due to its involvement with inflammation (Zavala et al., 2014; Ebersviller et al., 2012a, b; Doyle et al., 2004, 2007). We compared the gene expression levels in cells exposed to SOA generated in an outdoor chamber from photochemical oxidation of isoprene in the presence of NO and acidified sulfate seed aerosol to cells exposed to a dark control mixture of isoprene, NO, and acidified sulfate seed aerosol to isolate the effects of the isoprene-derived SOA on the cells using the EAVES. In addition, we collected SOA onto filters for subsequent resuspension exposure to ensure that effects observed from EAVES exposures were attributable to particle-phase organic products.

\section{Experimental section}

\subsection{Generation of SOA in the outdoor chamber facility}

SOA was generated by photochemically oxidizing a mixture of acidified sulfate seed aerosol, isoprene, and NO injected into an outdoor smog chamber facility. The outdoor chamber is a $120 \mathrm{~m}^{3}$ triangular cross-section Teflon chamber located on the roof of the Gillings School of Global Public Health, University of North Carolina at Chapel Hill. The chamber facility has been described in detail elsewhere by Lichtveld et al. (2012). The outdoor chamber facility is equipped with sampling lines that allow direct deposition exposure of cells, online chemical measurements, and filter collection for offline chemical analysis. Sampling lines run from the underside of the chamber directly to the chemistry lab below, where online measurement instruments and the direct deposition exposure device are located. Injection ports are also located on the underside of the chamber.

To generate isoprene-derived SOA, the chamber was operated on sunny days, under high relative humidity (RH), to allow natural sunlight to trigger photochemical reactions. Acidified sulfate seed aerosol was generated by nebuliz- 
ing an aqueous solution containing $0.06 \mathrm{M} \mathrm{MgSO}_{4}+0.06 \mathrm{M}$ $\mathrm{H}_{2} \mathrm{SO}_{4}$ into the chamber to a particle concentration of approximately $170 \mu \mathrm{g} \mathrm{m}^{-3}$, which was allowed to stabilize for $30 \mathrm{~min}$ to ensure a well-mixed condition. After stabilization, 3.5 ppmv isoprene (Sigma-Aldrich, $99 \%$ ) and $200 \mathrm{ppbv}$ NO (AirGas, $1.00 \%$ ) were injected into the chamber. Photochemical aging was allowed for approximately $1 \mathrm{~h}$ to reach the desired exposure conditions of $30-40 \mu \mathrm{g} \mathrm{m}^{-3}$ growth of isoprene-derived SOA on the pre-existing $170 \mu \mathrm{g} \mathrm{m}^{-3}$ of acidified sulfate aerosol. This chamber experiment was replicated on three separate sunny days with temperatures ranging from 24.9 to $26.8^{\circ} \mathrm{C}$ with a $\mathrm{RH}$ of approximately $70 \%$ in the chamber.

\subsection{Control chamber experiments}

As a dark chamber control, to isolate the effect of SOA on exposed cells, mixtures of isoprene, $\mathrm{NO}$, and $170 \mu \mathrm{g} \mathrm{m}^{-3}$ of acidified sulfate seed aerosol were injected into the chamber in the dark (after sunset). Conducting the chamber experiments in the dark ensured no photochemical oxidation of isoprene. The dark control was replicated on three different nights. Except for the absence of solar radiation (no SOA), all chamber operations and exposure conditions were similarly maintained.

As an added control to ensure that the device itself and the cell handling had no significant effect on cell cytotoxicity, cells were exposed in the EAVES to a clean chamber and compared to unexposed cells kept in an incubator for the same duration as the exposure. The cytotoxicity results ensured that there is no effect of chamber conditions and device operation on the cells.

\subsection{Cell culture}

Human bronchial epithelial (BEAS-2B) cells were maintained in keratinocyte growth medium (KGM BulletKit; Lonza), a serum-free keratinocyte basal medium (KBM) supplemented with $0.004 \%$ of bovine pituitary extract and $0.001 \%$ of human epidermal growth factor, insulin, hydrocortisone, and GA-1000 (gentamicin, amphotericin B), and passaged weekly. Passage number for photochemical exposures and dark control exposures varied between 52 and 60. Because BEAS-2B are an immortalized line of human bronchial epithelium, there are limitations with its use such as it being genetically homogeneous, being a single cell type, and being SV-40-transformed (Reddel et al., 1988). However, BEAS-2B is a stable, proliferative cell line shown to be useful in airway inflammation studies such as ours (Devlin et al., 1994).

\subsection{Direct deposition exposure}

In preparation for air-liquid interface exposures, cells were seeded onto collagen-coated Millicell cell culture inserts ( $30 \mathrm{~mm}$ diameter, $0.4 \mu \mathrm{m}$ pore size, $4.2 \mathrm{~cm}^{2}$ filter area; Milli- pore, Cambridge, MA) at a density of $2.0 \times 10^{5}$ cells per well $24 \mathrm{~h}$ prior to exposure. At the time of exposure, cells reached $\sim 80 \%$ confluence, confirmed through microscopy. Immediately before exposure, cell medium was removed from the apical and basolateral sides of two seeded Millicell cell culture inserts. One insert was transferred to a titanium dish containing $1.5 \mathrm{~mL}$ of keratinocyte basal medium (KBM; Lonza), supplying cells with nutrients from the basolateral side and constant moisture while allowing exposure to be performed at an air-liquid interface. The other insert was transferred into a six-well plate with $2 \mathrm{~mL}$ of $\mathrm{KBM}$ and placed in the incubator as an unexposed control.

Cells were exposed to chamber-generated isoprene SOA using the EAVES located in the laboratory directly beneath the outdoor chamber (de Bruijne et al., 2009; Lichtveld et al., 2012). The EAVES, located in an incubator at $37^{\circ} \mathrm{C}$, sampled chamber air at $1 \mathrm{~L} \mathrm{~min}^{-1}$. The target $\mathrm{RH}$ in the chamber during EAVES exposures was approximately $70 \%$. Exposure time was $1 \mathrm{~h}$ commencing when target exposure conditions were achieved in the outdoor chamber for both photochemical and dark control experiments. Detailed description of the EAVES can be found in de Bruijne et al. (2009).

Following exposure, the cell culture insert was transferred to a six-well tissue culture plate containing $2 \mathrm{~mL}$ of fresh KBM. The control Millicell was also transferred to $2 \mathrm{~mL}$ of fresh KBM. Nine hours post-exposure, extracellular medium was collected and total RNA was isolated using Trizol (Life Technologies), consistent with past studies (de Bruijne et al., 2009). Extracellular medium and the extracted RNA samples were stored at -20 and $-80^{\circ} \mathrm{C}$, respectively, until further analysis. For quality assurance purposes, the RNA concentration and integrity were assessed using a Nanodrop 2000c spectrophotometer (Thermo Scientific) and a Bioanalyzer 2100 (Agilent Technologies) over the period of storage. No changes were observed under the given storage conditions.

\subsection{Filter resuspension exposure}

Chamber particles were collected, concurrently with EAVES sampling, onto Teflon membrane filters (47 mm diameter, $1.0 \mu \mathrm{m}$ pore size; Pall Life Science) for photochemical (light) and dark chamber experiments to be used for chemical analysis and resuspension exposures. The resuspension experiments served as a control for possible effects of gaseous components such as ozone $\left(\mathrm{O}_{3}\right)$ and $\mathrm{NO}_{x}$ present in the direct deposition experiments; however, prior studies have shown that gaseous components do not yield cellular responses within the EAVES device (de Bruijne et al., 2009; Ebersviller et al., 2012a, b). Mass loadings of SOA collected on the filters were calculated from sampling volumes and average aerosol mass concentrations in the chamber during the sampling period. A density correction of $1.6 \mathrm{~g} \mathrm{~cm}^{-3}$ (Riedel et al., 2016) and $1.25 \mathrm{~g} \mathrm{~cm}^{-3}$ (Kroll et al., 2006) was applied to convert the measured volume concentrations to mass concentrations for the acidified sulfate seed and SOA growth, respectively. 
The particles collected on Teflon filter membranes for resuspension cell exposure were extracted by sonication in highpurity methanol (LC/MS CHROMASOLV, Sigma-Aldrich). Filter samples from multiple experiments were combined and the combined filter extract was dried under a gentle stream of nitrogen $\left(\mathrm{N}_{2}\right)$. KBM medium was then added into the extraction vials to re-dissolve SOA constituents.

In preparation for filter resuspension exposures, cells were seeded in 24-well plates at a density of $2.5 \times 10^{4}$ cells per well in $250 \mu \mathrm{L}$ of KGM 2 days prior to exposure. At the time of exposure when cells reached $\sim 80 \%$ confluence, cells were washed twice with phosphate-buffered saline (PBS) buffer, and then exposed to KBM containing 0.01 and $0.1 \mathrm{mg} \mathrm{mL}^{-1}$ isoprene SOA extract from photochemical experiment and seed particles from dark control experiments.

Following a $9 \mathrm{~h}$ exposure, extracellular medium was collected and total RNA was isolated using Trizol (Life Technologies) and stored alongside samples from direct deposition exposures until further analysis.

\subsection{Chemical and physical characterization of exposures}

Online and offline techniques were used to characterize the SOA generated in the chamber. The online techniques measured the gas-phase species $\left(\mathrm{NO}, \mathrm{NO}_{x}, \mathrm{O}_{3}\right)$ and the physical properties of the aerosol continuously throughout the chamber experiments. Offline techniques measured aerosol-phase species collected onto Teflon membrane filters ( $47 \mathrm{~mm}$ diameter, $1.0 \mu \mathrm{m}$ pore size; Pall Life Science) from photochemical and dark chamber experiments. Filter samples were stored in $20 \mathrm{~mL}$ scintillation vials protected from light at $-20^{\circ} \mathrm{C}$ until analyses.

Real-time aerosol size distributions were measured using a differential mobility analyzer (DMA, Brechtel Manufacturing Inc.) coupled to a mixing condensation particle counter (MCPC, model 1710, Brechtel Manufacturing Inc.) located in the laboratory directly underneath the chamber. $\mathrm{O}_{3}$ and $\mathrm{NO}_{x}$ were measured with a ML 9811 series ozone photometer (Teledyne Monitor Labs, Englewood, CO) and ML 9841 series $\mathrm{NO}_{x}$ analyzer (American Ecotech, Warren RI), respectively. Data were collected at $1 \mathrm{~min}$ intervals using a data acquisition system (ChartScan/1400) interfaced to a computer. The presence of isoprene in the chamber was confirmed and quantified using a Varian 3800 gas chromatograph (GC) equipped with a flame ionization detector (FID).

Chemical characterization of SOA constituents was conducted offline from extracts of filters collected from chamber experiments by a gas chromatograph interfaced with an electron ionization quadrupole mass spectrometer (GC/EI-MS) or by an ultra-performance liquid chromatograph interfaced with a high-resolution quadrupole time-of-flight mass spectrometer equipped with electrospray ionization (UPLC/ESIHR-QTOFMS). Detailed operating conditions for the GC/EIMS and UPLC/ESI-HR-QTOFMS analyses as well as de- tailed filter extraction protocols have been described previously by Lin et al. (2012). For GC/EI-MS analysis, filter extracts were dried under a gentle stream of $\mathrm{N}_{2}$ and trimethylsilylated by the addition of $100 \mu \mathrm{L}$ of BSTFA + TMCS (99:1 $v / v$, Supelco) and $50 \mu \mathrm{L}$ of pyridine (anhydrous, $99.8 \%$, Sigma-Aldrich) and heated at $70^{\circ} \mathrm{C}$ for $1 \mathrm{~h}$. For UPLC/ESIHR-QTOFMS analysis, residues of filter extracts were reconstituted with $150 \mu \mathrm{L}$ of a $50: 50(v / v)$ solvent mixture of high-purity water and methanol.

The isoprene-derived SOA markers - 2-methyltetrols, isomeric 3-methyltetrahydrofurans-3,4-diols (3-MeTHF-3,4diols), and 2-methylglyceric acid, synthesized according to the published procedures (Lin et al., 2013b; Zhang et al., 2012) - were available in-house as authentic standards to quantify the major components of isoprene SOA. 2Methyltetrol organosulfates, synthesized as a mixture of tetrabutylammonium salts, were also available as a standard. Purity was determined to be $>99 \%$ by ${ }^{1} \mathrm{H}$ NMR and UPLC/ESI-QTOFMS analysis (Budisulistiorini et al., 2015). The $\mathrm{C}_{5}$-alkene triols and IEPOX dimer were quantified using the response factor obtained for the synthetic 2-methyltetrols.

A representative ambient $\mathrm{PM}_{2.5}$ sample collected from the rural southeastern US (Yorkville, GA) (Lin et al., 2013a) during the summer of 2010 was analyzed in an identical manner to confirm atmospheric relevance of the chamber-generated SOA constituents.

\subsection{Cytotoxicity assay}

Cytotoxicity was assessed through measurement of lactate dehydrogenase (LDH) released into the extracellular medium from damaged cells using the LDH cytotoxicity detection kit (Takara). To ensure that the EAVES device itself and operation procedure had no effect on cytotoxicity, the LDH release from cells exposed to clean chamber air was measured. LDH release by cells exposed via the EAVES to the photochemically aged (light) and non-photochemically aged (dark) particles was compared to release from unexposed cells maintained in the incubator for the same duration. For the resuspension exposures, LDH release by cells exposed to SOA through resuspended extract of photochemically aged and non-photochemically aged particles was compared to release by cells maintained in KBM only. Additionally, LDH release from the light exposures, dark control, and resuspension exposures was compared to release by positive control cells exposed to $1 \%$ Triton X-100 to ensure that cell death would not affect gene expression results.

\subsection{Gene expression analysis}

We chose to measure the levels of the inflammationrelated mRNA in the BEAS-2B cells exposed to isoprenederived SOA generated in our outdoor chamber because various particle types are capable of sequestering cytokines (Seagrave, 2008). Other direct deposition studies 
have also used mRNA transcripts as a proxy for cytokine production (Hawley et al., 2014a, b; Hawley and Volckens, 2013; Volckens et al., 2009; Lichtveld et al., 2012). Changes in $I L-8$ and $C O X-2$ mRNA levels were measured using a QuantiTect SYBR Green RT-PCR kit (Qiagen) and QuantiTect primer assays for Hs_ACTB_1_SG (catalog no. QT00095431), Hs_PTGS2_1_SG (catalog no. QT00040586), and Hs_CXCL8_1_SG (catalog no. QT00000322) for one-step RT-PCR analysis. All mRNA levels were normalized against $\beta$-actin mRNA, which was used as a housekeeping gene. The relative expression levels (i.e., fold change) of $I L-8$ and $C O X-2$ were calculated using the comparative cycle threshold $\left(2^{-\Delta \Delta \mathrm{CT}}\right)$ method (Livak and Schmittgen, 2001). For EAVES exposures, changes in $I L-8$ and $C O X-2$ from isoprene-derived SOA exposed cells were compared to cells exposed to the dark controls. Similarly, for resuspension exposures, changes in $I L-8$ and $C O X-2$ from isoprene-derived SOA exposed cells were compared to cells exposed to particles collected under dark conditions.

\subsection{Statistical analysis}

The software package GraphPad Prism 4 (GraphPad) was used for all statistical analyses. All data were expressed as mean \pm SEM (standard error of means). Comparisons between data sets for cytotoxicity and gene expression analysis were made using unpaired $t$ test with Welch's correction. Significance was defined as $p<0.05$.

\section{Results and discussion}

\subsection{Physical and chemical characterization of exposure}

Figure 1 shows the change in particle mass concentration and gas $\left(\mathrm{NO}, \mathrm{NO}_{x}, \mathrm{O}_{3}\right.$ ) concentration over time during typical photochemical and dark control experiments. Under dark control conditions (Fig. 1a) there is no increase in aerosol mass concentration following isoprene injection. Average total aerosol mass concentration was $155.0 \pm 2.69 \mathrm{\mu g} \mathrm{m}^{-3}$ (1 standard deviation) with no particle mass attributable to organic material.

In contrast, Fig. 1b shows an increase in aerosol mass concentration $1 \mathrm{~h}$ after isoprene injection, which can be attributed to the photochemical oxidation of isoprene and subsequent production and reactive uptake of its oxidation products. The average increase in aerosol mass concentration attributable to SOA formation for three daylight chamber experiments conducted on separate days was $44.5 \pm 5.7 \mu \mathrm{g} \mathrm{m}^{-3}$. Average total aerosol mass concentration during particle exposure was $173.1 \pm 4.2 \mu \mathrm{g} \mathrm{m}^{-3}$.

$\mathrm{O}_{3}$ and $\mathrm{NO}_{x}$ concentrations measured during EAVES exposure were approximately 270 and 120 ppb for photochemical experiments. For dark control experiments (e.g., Fig. 1a), the $\mathrm{O}_{3}$ and $\mathrm{NO}_{x}$ concentrations were approximately 15 and $180 \mathrm{ppb}$. Previous studies characterizing the EAVES device
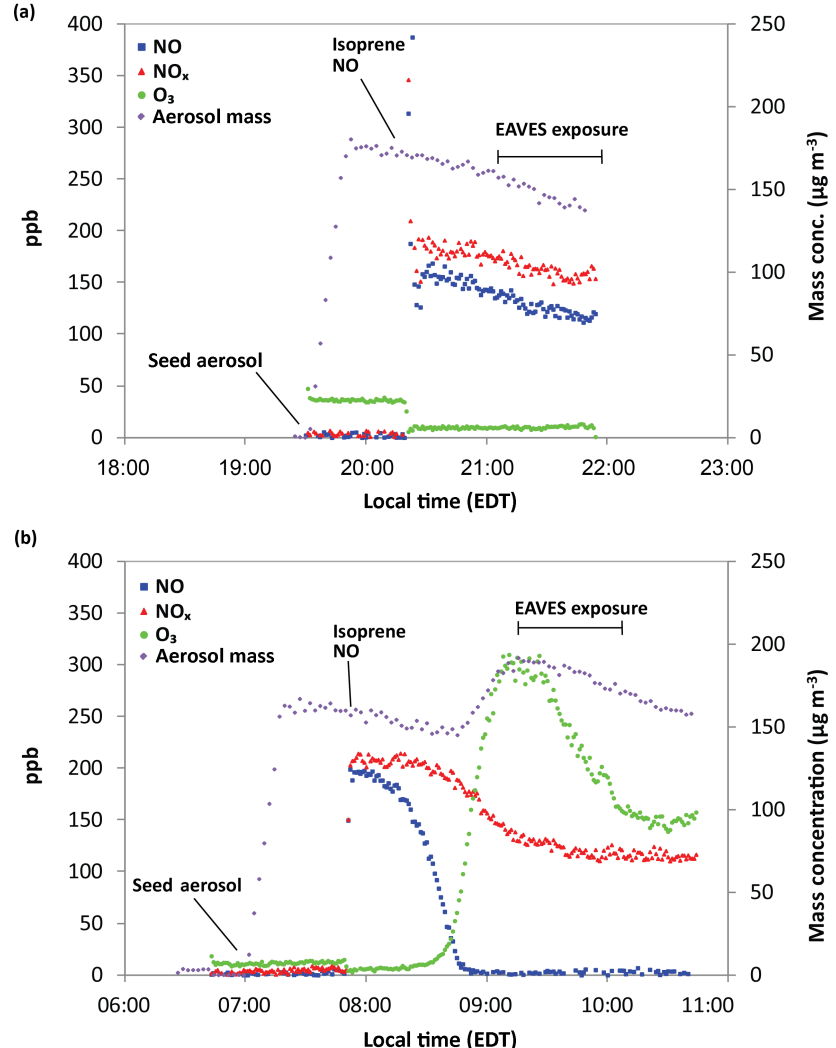

Figure 1. Aerosol mass concentration and gas-phase product concentrations over time for (a) dark control chamber experiment and (b) photochemically produced isoprene-derived SOA exposure chamber experiment.

show definitively that gas-phase products do not induce cell response (de Bruijne et al., 2009). However, resuspension exposures were conducted in addition to EAVES exposure to ensure that biological effects were attributable to only particle-phase constituents and not gas-phase products such as $\mathrm{O}_{3}$ and $\mathrm{NO}_{x}$.

The chemical composition of aerosol, collected onto filters concurrently with cell exposure and characterized by GC/EIMS and UPLC/ESI-HR-QTOFMS, are shown in Fig. 2. No isoprene SOA tracers were observed in the filters collected from dark control experiments. The dominant particle-phase products of the isoprene SOA collected from photochemical experiments are derived from the low-NO channel, where IEPOX reactive uptake onto acidic sulfate aerosol dominates, including 2-methyltetrols, $\mathrm{C}_{5}$-alkene triols, isomeric 3-MeTHF-3,4-diols, IEPOX-derived dimers, and IEPOXderived organosulfates. The sum of the IEPOX-derived SOA constituents quantified by the available standards accounted for $\sim 80 \%$ of the observed SOA mass. The MAE-derived SOA constituents 2-methylglyceric acid and the organosulfate derivative of MAE, derived from the high-NO channel, accounted for $1.4 \%$ of the observed SOA mass, confirming that particle-phase products generated were predominantly 


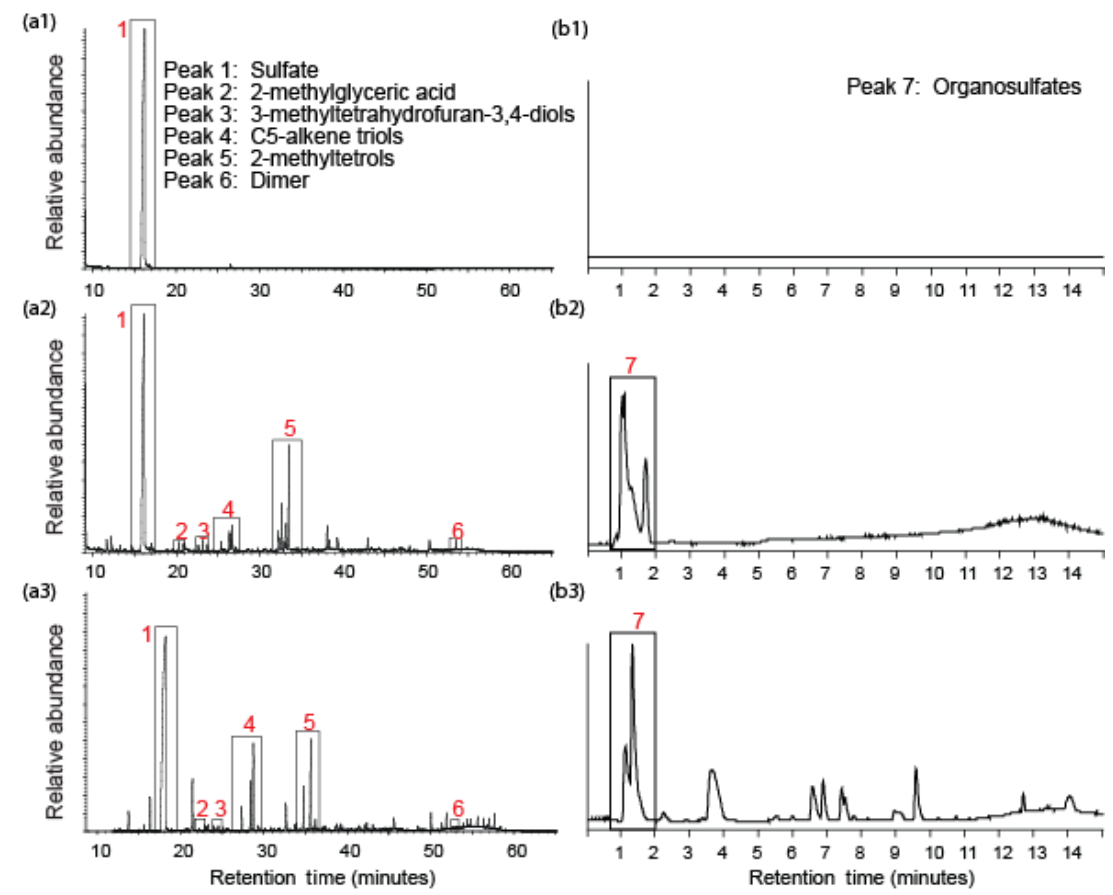

Figure 2. (a) GC/EI-MS total ion chromatograms (TICs) and (b) UPLC/ESI-HR-QTOFMS base peak chromatograms (BPCs) from a (1) dark control chamber experiment, (2) isoprene-derived SOA exposure chamber experiment, and (3) $\mathrm{PM}_{2.5}$ sample collected from Yorkville, GA, during summer 2010 .

formed from the reactive uptake of IEPOX onto acidic sulfate aerosols. As demonstrated in Fig. 2, all the same particlephase products are measured in the $\mathrm{PM}_{2.5}$ sample collected in Yorkville, GA (a typical low-NO region), demonstrating that the composition of the chamber-generated SOA is atmospherically relevant. Recent SOA tracer measurements from the Southern Oxidant and Aerosol Study (SOAS) campaign at Look Rock, TN; Centerville, AL; and Birmingham, AL, also support the atmospheric relevance of IEPOX-derived SOA constituents that dominate the isoprene SOA mass in summer in the southeastern US (Budisulistiorini et al., 2016; Rattanavaraha et al., 2016).

\subsection{Cytotoxicity}

LDH release for cells exposed using the EAVES device is expressed as a fold change relative to the unexposed incubator control. For resuspension exposures, LDH release is expressed as fold change relative to cells exposed to KBM only. Results shown in Fig. 3a confirm that there is no effect of chamber conditions and device operation on the cells when comparing LDH release from cells exposed to a clean air chamber and cells unexposed in an incubator. Additionally, LDH release from all exposure conditions in EAVES exposed cells (Fig. 3b) and resuspension exposed cells (Fig. 3c) is negligible relative to positive controls exposed to $1 \%$ Triton X-100, confirming that the exposure concentration of isoprene-derived SOA utilized in this study was not cyto- toxic. All cytotoxicity results ensured that exposure conditions were not adversely affecting the cells or their gene expression.

\subsection{Pro-inflammatory gene expression}

Changes in the mRNA levels of $I L-8$ and $C O X-2$ from cells exposed to isoprene-derived SOA using the EAVES are shown as fold changes relative to dark controls in Fig. 4. This comparison, as well as the results of the resuspension experiment discussed below, ensures that all effects seen in the cells are attributable to the isoprene-derived SOA and no other factors. A $1 \mathrm{~h}$ exposure to a mass concentration of approximately $45 \mu \mathrm{g} \mathrm{m}^{-3}$ of organic material was sufficient to significantly alter gene expression of the inflammatory biomarkers in bronchial epithelial cells. Based on deposition efficiency characterized by de Bruijne et al. (2009), the estimated dose was $0.29 \mu \mathrm{g} \mathrm{cm}^{-2}$ of total particle mass with $23 \%$ attributable to organic material formed from isoprene photooxidation $\left(0.067 \mu \mathrm{g} \mathrm{cm}^{-2}\right.$ of SOA).

Changes in the mRNA levels of $I L-8$ and $C O X-2$ from cells exposed to resuspended isoprene-derived SOA collected from photochemical experiments are shown as fold changes relative to cells exposed to resuspended particles from dark control experiments in Fig. 5. At a low dose of $0.01 \mathrm{mg} \mathrm{mL}^{-1}$ of isoprene SOA extract there is no significant increase in $I L-8$ and $C O X-2$ mRNA expression. The isoprene SOA extract, however, induces a response at a dose of 

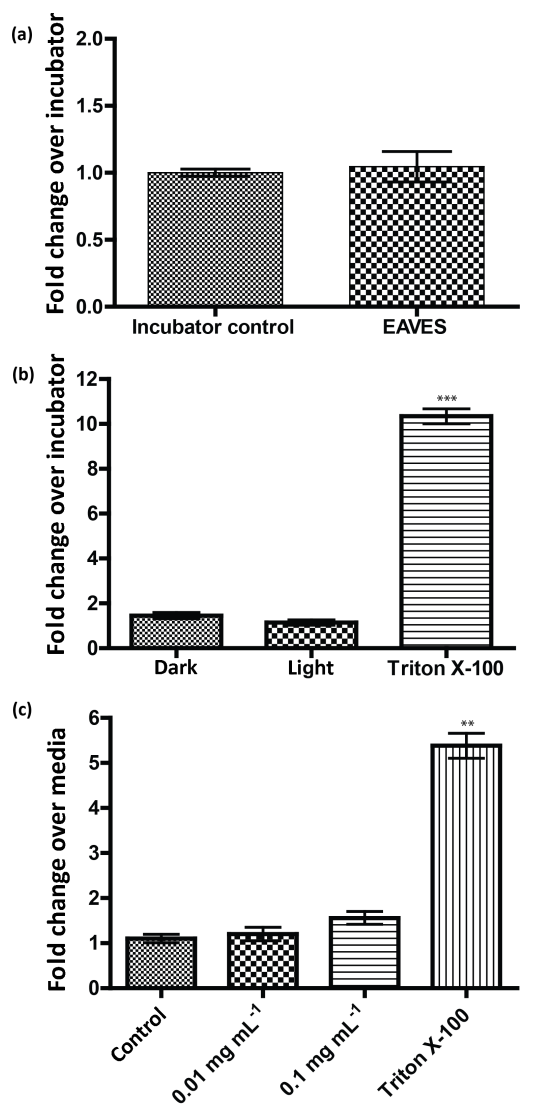

Figure 3. LDH release for (a) clean air controls; (b) EAVES exposures, normalized to incubator control; and (c) resuspension exposures, normalized to KBM-only control. ${ }^{* *} p<0.005$ and $* * * \quad p<0.0005$.

$0.1 \mathrm{mg} \mathrm{mL}^{-1}$. The statistically significant increase in mRNA expression from the resuspension exposure at $0.1 \mathrm{mg} \mathrm{mL}^{-1}$ confirms that similar fold changes observed for both $I L-8$ and $C O X-2$ from the EAVES exposures are not attributable to gaseous photooxidation products, such as $\mathrm{O}_{3}$, and support the characterization of the EAVES as a particle exposure device (de Bruijne et al., 2009).

The similar fold change observed in both the EAVES exposure and resuspension exposure, in addition to confirming that the biological effects can be attributed to the particle-phase photochemical products (isoprene-derived SOA), suggests that exposure by resuspension is appropriate for isoprene-derived SOA and may yield results similar to direct deposition exposures. Unlike diesel particulate extracts, which agglomerate during resuspension exposures, isoprenederived SOA constituents are water-soluble based on reversephase LC separations (Surratt et al., 2006; Lin et al., 2012) and remain well mixed in the cell medium used for exposure. Therefore, resuspension exposures do not appear to be a limitation for toxicological assessments of isoprene SOA.
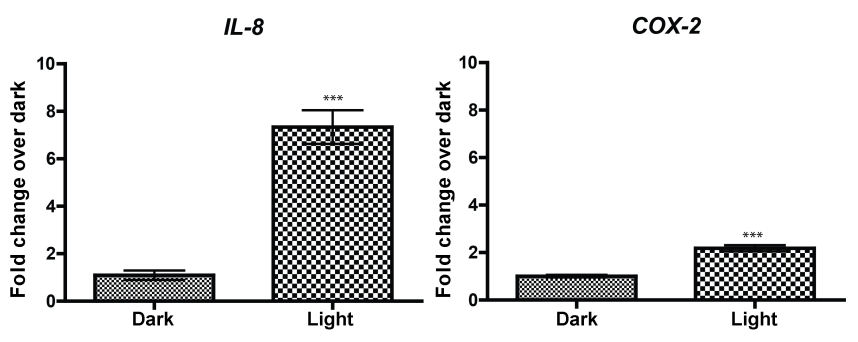

Figure 4. $I L-8$ and $C O X-2$ mRNA expression induced by exposure to isoprene-derived SOA using EAVES device all normalized to dark control experiments and against the housekeeping gene, $\beta$ actin. All experiments conducted in triplicate. ${ }^{* * *} p<0.0005$.
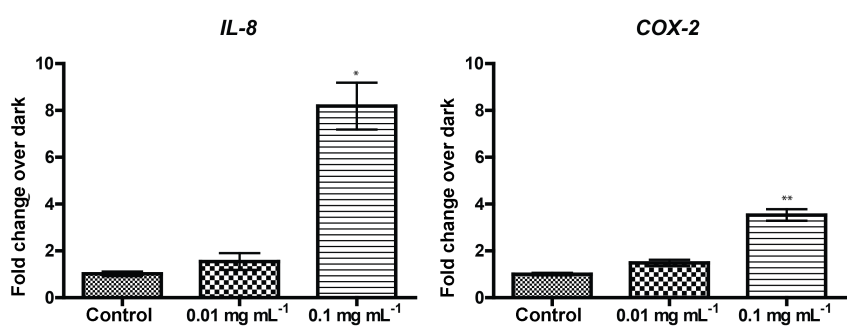

Figure 5. $I L-8$ and $C O X-2$ expression induced by exposure to isoprene-derived SOA using resuspension method all normalized to dark control experiments and against the housekeeping gene, $\beta$-actin. All experiments conducted in triplicate. ${ }^{*} p<0.05$ and ** $p<0.005$.

\subsection{Biological implications}

The goal of this study was to initially identify potential biological response associated with exposure to isoprenederived SOA by using a direct exposure device as a model that has both atmospheric and physiological relevance. With this model, a dose of $0.067 \mu \mathrm{g} \mathrm{cm}^{-2}$ of isoprene SOA induced statistically significant increases in $I L-8$ and $C O X-2$ mRNA levels in exposed BEAS-2B cells. There are many ways to classify in vitro particle dosimetry based on the various properties of particles (Paur et al., 2011). For this direct deposition study, we chose to classify dose as SOA mass deposition per surface area of the exposed cells to mimic lung deposition. Gangwal et al. (2011) used a multiplepath particle dosimetry (MPPD) model to estimate that the lung deposition of ultrafine particles ranges from 0.006 to $0.02 \mu \mathrm{g} \mathrm{cm}^{-2}$ for a $24 \mathrm{~h}$ exposure to a particle concentration of $0.1 \mathrm{mg} \mathrm{m}^{-3}$. Based on this estimate, a dose of $0.067 \mu \mathrm{g} \mathrm{cm}^{-2}$ of isoprene SOA in our study can be considered a prolonged exposure over the course of a week. In fact, most other in vitro studies require dosing cells at a high concentration sometimes close to a lifetime exposure to obtain a cellular response. Despite this limitation, in vitro exposures serve as a necessary screening tool for toxicity (Paur et al., 2011). 
Our findings are consistent with other studies showing that photochemical oxidation of similar chemical mixtures increases toxicity in cell culture models and elevates expression of inflammatory biomarker genes (Lichtveld et al., 2012; Rager et al., 2011). Previous in vitro studies using a gasphase-only exposure system have shown that gas-phase products of isoprene photooxidation significantly enhance cytotoxicity and $I L-8$ expression (Doyle et al., 2004, 2007).

By choosing $I L-8$ and $C O X-2$ as our genes of interest, we are able to compare our results to other studies of known harmful particle exposures. In a similar study using the EAVES, normal human bronchial epithelial (NHBE) cells exposed to $1.10 \mu \mathrm{g} \mathrm{cm}^{-2}$ diesel particulate matter showed less than a 2-fold change over controls in both $I L-8$ and $C O X$ 2 mRNA expression (Hawley et al., 2014b). In another study, A549 human lung epithelial cells were exposed by direct deposition for $1 \mathrm{~h}$ to photochemically aged diesel exhaust particulates at a dose of $2.65 \mathrm{~g} \mathrm{~cm}^{-2}$ from a 1980 Mercedes or a 2006 Volkswagen (Lichtveld et al., 2012). Exposure to aged Mercedes particulates induced a 4-fold change in $I L$ 8 and $\sim 2$-fold change in $C O X-2$ mRNA expression, while exposure to aged Volkswagen particulates induced a change of $\sim 1.5$-fold in $I L-8$ and 2-fold in $C O X-2$ mRNA expression (Lichtveld et al., 2012). Although the differences in cell types preclude direct comparisons, the finding of significant increases in $C O X-2$ and $I L-8$ expression at doses much lower than reported for comparable increases in gene expression levels induced by photochemically aged diesel particulates is notable.

$I L-8$ and $C O X-2$ are both linked to inflammation and oxidative stress (Kunkel et al., 1991; Uchida, 2008). $I L-8$ is a potent neutrophil chemotactic factor in the lung and its expression by various cells plays a crucial role in neutrophil recruitment leading to lung inflammation (Kunkel et al., 1991). $C O X-2$ is the inducible form of the cyclooxygenase enzyme, regulated by cytokines and mitogens, and is responsible for prostaglandin synthesis associated with inflammation (FitzGerald, 2003). Consistent with the reports that $I L-8$ and COX-2 play important roles in lung inflammation (Nocker et al., 1996; Li et al., 2013), in vivo studies have shown that isoprene oxidation products cause airflow limitation and sensory irritation in mice (Rohr et al., 2003). In humans, the role of $I L-8$ and $C O X-2$ in lung inflammation can be associated with diseases such as chronic obstructive pulmonary disease and asthma (Nocker et al., 1996; Peng et al., 2008; Fong et al., 2000).

The mechanism by which isoprene SOA causes elevation of the inflammatory markers $I L-8$ and $C O X-2$ is not yet fully understood. However, recent work from our laboratory using the acellular dithiothreitol (DTT) assay demonstrated that isoprene-derived SOA has significant ROS generation potential (Kramer et al., 2016). High levels of ROS in cells can overwhelm the antioxidant defense and lead to cellular oxidative stress (Sies, 1991; Bowler and Crapo, 2002; Li et al., 2003). Following the discovery of the potential importance of isoprene SOA in generating ROS, Lin et al. (2016) showed that isoprene SOA formed from the reactive uptake of epoxides alters levels of oxidative stress-associated genes, including $C O X-2$ in human lung cells. Oxidative stress caused by ROS plays a major role in lung inflammation and the induction of oxidative stress can lead to $I L-8$ expression (Tao et al., 2003; Yan et al., 2015). Specifically, oxidants can activate the transcription factor $\mathrm{NF}-\kappa \mathrm{B}$, which regulates a wide range of inflammatory genes including $I L-8$ and $C O X-2$ (Barnes and Adcock, 1997; Schreck et al., 1992). Therefore, isoprene SOA may cause increases in both $I L-8$ and $C O X-2$ primarily through an oxidative stress response. Additionally, the relationship between $I L-8$ and $C O X-2$ can also explain the observed increase in $I L-8$ gene expression as the production of $I L-8$ can be stimulated through a $C O X$-2-dependent mechanism in airway epithelial cells (Peng et al., 2008).

In vitro studies such as this one using a direct deposition model cannot fully elucidate mechanisms of lung inflammation and potential pathogenesis but serve as a necessary part of hazard characterization, particularly for a complex air mixture that has not been fully studied (Hayashi, 2005; Paur et al., 2011). Ozone exposure studies have shown that comparable dose and effect measurements for $I L-8$ and $C O X-2$ can be found between in vivo and in vitro exposures, which adds promise to extrapolating effects seen in vitro to effects in vivo (Hatch et al., 2014). In vivo effects associated with isoprene SOA exposure in vitro cannot be inferred as it is a different system from ozone, so further in vitro studies exploring the health implication of the elevation of $I L-8$ and $C O X-2$ due specifically to isoprene SOA exposure are necessary and may in turn justify further extension to in vivo work.

\section{Conclusions}

This study indicates that an atmospherically relevant composition of isoprene-derived SOA is capable of increasing the expression of $I L-8$ and $C O X-2$ in human bronchial epithelial cells. The present study is an initial step in a long planned analysis of the biological impacts of isoprene SOA exposure on lung cells. The SOA was generated as NO levels approached zero, which represents conditions characteristic of urban locales downwind of rural isoprene sources. As shown in Fig. 2, the aerosol generated for exposures in this study are chemically similar to fine aerosol samples collected from the southeastern US, which indicates that the chamber exposures are representative of exposures that may be encountered by populations in regions where isoprene emissions interact with anthropogenic pollutants. The same particlephase products found in our photochemical experiments have been measured in significant quantities (accounting on average for $33 \%$ of fine organic aerosol mass) in ambient fine organic particles collected in the southeastern US (Lin et al., 2013b; Budisulistiorini et al., 2013, 2016; Rattanavaraha et 
al., 2016) and in other isoprene-rich environments (Hu et al., 2015). The results of this study show that, because of its abundance, isoprene SOA may be a public health concern warranting further toxicological investigation through in vitro or in vivo work.

\section{Data availability}

Data can be made available upon request to the corresponding author (Surratt). Data sets that could be made available include aerosol size distributions, gas-phase constituent concentrations $\left(\mathrm{NO}_{x}, \mathrm{O}_{3}\right)$, characterization of isoprene $\mathrm{SOA}$ tracers from GC/EI-MS and UPLC/ESI-HR-QTOFMS, cytotoxicity data, and RT-PCR data.

Acknowledgements. Research described in this article was conducted under contract to the Health Effects Institute (HEI), an organization jointly funded by the United States Environmental Protection Agency (EPA) (Assistance Award No. R-82811201), and certain motor vehicle and engine manufacturers. The contents of this article do not necessarily reflect the views of HEI, or its sponsors, nor do they necessarily reflect the views and policies of the EPA or motor vehicle and engine manufacturers. Maiko Arashiro was supported by a graduate fellowship provided by the National Science Foundation (DGE-0646083), from the Center for Faculty Excellence, University of North Carolina at Chapel Hill, and in part by a grant from the National Institute of Environmental Health Sciences (T32-ES007018).

Edited by: Y. Rudich

Reviewed by: X. Qin and two anonymous referees

\section{References}

Barnes, P. J. and Adcock, I. M.: NF-kB: a pivotal role in asthma and a new target for therapy, Am. J. Physiol, 265, 577-506, 1997.

Bowler, R. P. and Crapo, J. D.: Oxidative stress in allergic respiratory diseases, J. Allergy Clin. Immun., 110, 349-356, doi:10.1067/mai.2002.126780, 2002.

Budisulistiorini, S. H., Canagaratna, M. R., Croteau, P. L., Marth, W. J., Baumann, K., Edgerton, E. S., Shaw, S. L., Knipping, E. M., Worsnop, D. R., Jayne, J. T., Gold, A., and Surratt, J. D.: Real-Time Continuous Characterization of Secondary Organic Aerosol Derived from Isoprene Epoxydiols in Downtown Atlanta, Georgia, Using the Aerodyne Aerosol Chemical Speciation Monitor, Environ. Sci. Technol., 47, 5686-5694, doi:10.1021/es400023n, 2013.

Budisulistiorini, S. H., Li, X., Bairai, S. T., Renfro, J., Liu, Y., Liu, Y. J., McKinney, K. A., Martin, S. T., McNeill, V. F., Pye, H. O. T., Nenes, A., Neff, M. E., Stone, E. A., Mueller, S., Knote, C., Shaw, S. L., Zhang, Z., Gold, A., and Surratt, J. D.: Examining the effects of anthropogenic emissions on isoprene-derived secondary organic aerosol formation during the 2013 Southern Oxidant and Aerosol Study (SOAS) at the Look Rock, Tennessee ground site, Atmos. Chem. Phys., 15, 8871-8888, 10.5194/acp15-8871-2015, 2015.
Budisulistiorini, S. H., Baumann, K., Edgerton, E. S., Bairai, S. T., Mueller, S., Shaw, S. L., Knipping, E. M., Gold, A., and Surratt, J. D.: Seasonal characterization of submicron aerosol chemical composition and organic aerosol sources in the southeastern United States: Atlanta, Georgia,and Look Rock, Tennessee, Atmos. Chem. Phys., 16, 5171-5189, doi:10.5194/acp-16-51712016, 2016.

Carlton, A. G., Wiedinmyer, C., and Kroll, J. H.: A review of Secondary Organic Aerosol (SOA) formation from isoprene, Atmos. Chem. Phys., 9, 4987-5005, doi:10.5194/acp-9-4987-2009, 2009.

de Bruijne, K., Ebersviller, S., Sexton, K. G., Lake, S., Leith, D., Goodman, R., Jetters, J., Walters, G. W., Doyle-Eisele, M., Woodside, R., Jeffries, H. E., and Jaspers, I.: Design and Testing of Electrostatic Aerosol In Vitro Exposure System (EAVES): An Alternative Exposure System for Particles, Inhal. Toxicol., 21, 91-101, doi:10.1080/08958370802166035, 2009.

Devlin, R. B., McKinnon, K. P., Noah, T., Becker, S., and Koren, H. S.: Ozone-induced release of cytokines and fibronectin by alveolar macrophages and airway epithelial cells, Am. J. Physiol.Lung C., 266, L612-L619, 1994.

Dockery, D. W., Pope, C. A., Xu, X. P., Spengler, J. D., Ware, J. H., Fay, M. E., Ferris, B. G., and Speizer, F. E.: An Association between Air-Pollution and Mortality in 6 United-States Cities, New Engl. J. Med., 329, 1753-1759, 10.1056/NEJM199312093292401, 1993.

Doyle, M., Sexton, K. G., Jeffries, H., Bridge, K., and Jaspers, I.: Effects of 1,3-butadiene, isoprene, and their photochemical degradation products on human lung cells, Environ. Health Persp., 112, 1488-1495, doi:10.1289/ehp.7022, 2004.

Doyle, M., Sexton, K. G., Jeffries, H., and Jaspers, I.: Atmospheric photochemical transformations enhance 1,3-butadiene-induced inflammatory responses in human epithelial cells: The role of ozone and other photochemical degradation products, Chem.Biol. Interact., 166, 163-169, doi:10.1016/j.cbi.2006.05.016, 2007.

Ebersviller, S., Lichtveld, K., Sexton, K. G., Zavala, J., Lin, Y.H., Jaspers, I., and Jeffries, H. E.: Gaseous VOCs rapidly modify particulate matter and its biological effects - Part 1: Simple VOCs and model PM, Atmos. Chem. Phys., 12, 12277-12292, doi:10.5194/acp-12-12277-2012, 2012a.

Ebersviller, S., Lichtveld, K., Sexton, K. G., Zavala, J., Lin, Y.-H., Jaspers, I., and Jeffries, H. E.: Gaseous VOCs rapidly modify particulate matter and its biological effects - Part 2: Complex urban VOCs and model PM, Atmos. Chem. Phys., 12, 1229312312, doi:10.5194/acp-12-12293-2012, 2012 b.

FitzGerald, G. A.: COX-2 and beyond: approaches to prostaglandin inhibition in human disease, Nat. Rev. Drug. Discov., 2, 879-890, 2003.

Fong, C. Y., Pang, L., Holland, E., and Knox, A. J.: TGF- $\beta 1$ stimulates IL-8 release, COX-2 expression, and PGE2release in human airway smooth muscle cells, Am. J. Physiol.-Lung C., 279, L201-L207, 2000.

Gangwal, S., Brown, J. S., Wang, A., Houck, K. A., Dix, D. J., Kavlock, R. J., and Hubal, E. A. C.: Informing Selection of Nanomaterial Concentrations for ToxCast in Vitro Testing Based on Occupational Exposure Potential, Environ. Health Persp., 119, 1539-1546, doi:10.1289/ehp.1103750, 2011. 
Gaschen, A., Lang, D., Kalberer, M., Savi, M., Geiser, T., Gazdhar, A., Lehr, C.-M., Bur, M., Dommen, J., Baltensperger, U., and Geiser, M.: Cellular Responses after Exposure of Lung Cell Cultures to Secondary Organic Aerosol Particles, Environ. Sci. Technol., 44, 1424-1430, doi:10.1021/es902261m, 2010.

Gaston, C. J., Riedel, T. P., Zhang, Z. F., Gold, A., Surratt, J. D., and Thornton, J. A.: Reactive Uptake of an Isoprene-Derived Epoxydiol to Submicron Aerosol Particles, Environ. Sci. Technol., 48, 11178-11186, 10.1021/es5034266, 2014.

Hatch, G. E., Duncan, K. E., Diaz-Sanchez, D., Schmitt, M. T., Ghio, A. J., Carraway, M. S., McKee, J., Dailey, L. A., Berntsen, J., and Devlin, R. B.: Progress in Assessing Air Pollutant Risks from In Vitro Exposures: Matching Ozone Dose and Effect in Human Airway Cells, Toxicol. Sci., 141, 198-205, doi:10.1093/toxsci/kfu115, 2014.

Hawley, B. and Volckens, J.: Proinflammatory effects of cookstove emissions on human bronchial epithelial cells, Indoor Air, 23, 4-13, doi:10.1111/j.1600-0668.2012.00790.x, 2013.

Hawley, B., L'Orange, C., Olsen, D. B., Marchese, A. J., and Volckens, J.: Oxidative Stress and Aromatic Hydrocarbon Response of Human Bronchial Epithelial Cells Exposed to Petro- or Biodiesel Exhaust Treated with a Diesel Particulate Filter, Toxicol. Sci., 141, 505-514, doi:10.1093/toxsci/kfu147, 2014a.

Hawley, B., McKenna, D., Marchese, A., and Volckens, J.: Time course of bronchial cell inflammation following exposure to diesel particulate matter using a modified EAVES, Toxicol. in Vitro, 28, 829-837, doi:10.1016/j.tiv.2014.03.001, 2014b.

Hayashi, Y.: Designing in vitro assay systems for hazard characterization. Basic strategies and related technical issues, Exp. Toxicol. Pathol., 57, 227-232, doi:10.1016/j.etp.2005.05.012, 2005.

Henze, D. K., Seinfeld, J. H., Ng, N. L., Kroll, J. H., Fu, T.-M., Jacob, D. J., and Heald, C. L.: Global modeling of secondary organic aerosol formation from aromatic hydrocarbons: highvs. low-yield pathways, Atmos. Chem. Phys., 8, 2405-2420, doi:10.5194/acp-8-2405-2008, 2008.

Hu, W. W., Campuzano-Jost, P., Palm, B. B., Day, D. A., Ortega, A. M., Hayes, P. L., Krechmer, J. E., Chen, Q., Kuwata, M., Liu, Y. J., de Sá, S. S., McKinney, K., Martin, S. T., Hu, M., Budisulistiorini, S. H., Riva, M., Surratt, J. D., St. Clair, J. M., Isaacman-Van Wertz, G., Yee, L. D., Goldstein, A. H., Carbone, S., Brito, J., Artaxo, P., de Gouw, J. A., Koss, A., Wisthaler, A., Mikoviny, T., Karl, T., Kaser, L., Jud, W., Hansel, A., Docherty, K. S., Alexander, M. L., Robinson, N. H., Coe, H., Allan, J. D., Canagaratna, M. R., Paulot, F., and Jimenez, J. L.: Characterization of a real-time tracer for isoprene epoxydiols-derived secondary organic aerosol (IEPOX-SOA) from aerosol mass spectrometer measurements, Atmos. Chem. Phys., 15, 11807-11833, doi:10.5194/acp-15-11807-2015, 2015.

Jang, M., Ghio, A. J., and Cao, G.: Exposure of BEAS-2B Cells to Secondary Organic Aerosol Coated on Magnetic Nanoparticles, Chem. Res. Toxicol., 19, 1044-1050, doi:10.1021/tx0503597, 2006.

Kelly, F. J. and Fussell, J. C.: Size, source and chemical composition as determinants of toxicity attributable to ambient particulate matter, Atmos. Environ., 60, 504-526, doi:10.1016/j.atmosenv.2012.06.039, 2012.

Kramer, A. J., Rattanavaraha, W., Zhang, Z., Gold, A., Surratt, J. D., and Lin, Y.-H.: Assessing the oxidative potential of isoprene- derived epoxides and secondary organic aerosol, Atmos. Environ., 130, 211-218, doi:10.1016/j.atmosenv.2015.10.018, 2016.

Krechmer, J. E., Coggon, M. M., Massoli, P., Nguyen, T. B., Crounse, J. D., Hu, W., Day, D. A., Tyndall, G. S., Henze, D. K., Rivera-Rios, J. C., Nowak, J. B., Kimmel, J. R., Mauldin, R. L., Stark, H., Jayne, J. T., Sipilä, M., Junninen, H., Clair, J. M. S., Zhang, X., Feiner, P. A., Zhang, L., Miller, D. O., Brune, W. H., Keutsch, F. N., Wennberg, P. O., Seinfeld, J. H., Worsnop, D. R., Jimenez, J. L., and Canagaratna, M. R.: Formation of Low Volatility Organic Compounds and Secondary Organic Aerosol from Isoprene Hydroxyhydroperoxide Low-NO Oxidation, Environ. Sci. Technol., 49, 10330-10339, doi:10.1021/acs.est.5b02031, 2015.

Kroll, J. H., Ng, N. L., Murphy, S. M., Flagan, R. C., and Seinfeld, J. H.: Secondary organic aerosol formation from isoprene photooxidation, Environ. Sci. Technol., 40, 1869-1877, doi:10.1021/es0524301, 2006.

Kunkel, S. L., Standiford, T., Kasahara, K., and Strieter, R. M.: Interleukin-8 (Il-8) - the Major Neutrophil Chemotactic Factor in the Lung, Exp. Lung Res., 17, 17-23, doi:10.3109/01902149109063278, 1991.

Li, H., Edin, M. L., Bradbury, J. A., Graves, J. P., DeGraff, L. M., Gruzdev, A., Cheng, J., Dackor, R. T., Wang, P. M., Bortner, C. D., Garantziotis, S., Jetten, A. M., and Zeldin, D. C.: Cyclooxygenase-2 Inhibits T Helper Cell Type 9 Differentiation during Allergic Lung Inflammation via Downregulation of IL-17RB, Am. J. Resp. Crit. Care, 187, 812-822, doi:10.1164/rccm.201211-2073OC, 2013.

Li, N., Hao, M., Phalen, R. F., Hinds, W. C., and Nel, A. E.: Particulate air pollutants and asthma: A paradigm for the role of oxidative stress in PM-induced adverse health effects, Cl. Immunol., 109, 250-265, doi:10.1016/j.clim.2003.08.006, 2003.

Lichtveld, K. M., Ebersviller, S. M., Sexton, K. G., Vizuete, W., Jaspers, I., and Jeffries, H. E.: In Vitro Exposures in Diesel Exhaust Atmospheres: Resuspension of PM from Filters versus Direct Deposition of PM from Air, Environ. Sci. Technol., 46, 9062-9070, doi:10.1021/es301431s, 2012.

Lim, S. S., Vos, T., Flaxman, A. D., Danaei, G., Shibuya, K., AdairRohani, H., AlMazroa, M. A., Amann, M., Anderson, H. R., Andrews, K. G., Aryee, M., Atkinson, C., Bacchus, L. J., Bahalim, A. N., Balakrishnan, K., Balmes, J., Barker-Collo, S., Baxter, A., Bell, M. L., Blore, J. D., Blyth, F., Bonner, C., Borges, G., Bourne, R., Boussinesq, M., Brauer, M., Brooks, P., Bruce, N. G., Brunekreef, B., Bryan-Hancock, C., Bucello, C., Buchbinder, R., Bull, F., Burnett, R. T., Byers, T. E., Calabria, B., Carapetis, J., Carnahan, E., Chafe, Z., Charlson, F., Chen, H., Chen, J. S., Cheng, A. T.-A., Child, J. C., Cohen, A., Colson, K. E., Cowie, B. C., Darby, S., Darling, S., Davis, A., Degenhardt, L., Dentener, F., Des Jarlais, D. C., Devries, K., Dherani, M., Ding, E. L., Dorsey, E. R., Driscoll, T., Edmond, K., Ali, S. E., Engell, R. E., Erwin, P. J., Fahimi, S., Falder, G., Farzadfar, F., Ferrari, A., Finucane, M. M., Flaxman, S., Fowkes, F. G. R., Freedman, G., Freeman, M. K., Gakidou, E., Ghosh, S., Giovannucci, E., Gmel, G., Graham, K., Grainger, R., Grant, B., Gunnell, D., Gutierrez, H. R., Hall, W., Hoek, H. W., Hogan, A., Hosgood Iii, H. D., Hoy, D., Hu, H., Hubbell, B. J., Hutchings, S. J., Ibeanusi, S. E., Jacklyn, G. L., Jasrasaria, R., Jonas, J. B., Kan, H., Kanis, J. A., Kassebaum, N., Kawakami, N., Khang, Y.-H., Khatibzadeh, S., Khoo, J.-P., Kok, C., Laden, F., Lalloo, R., Lan, Q., Lathlean, T., 
Leasher, J. L., Leigh, J., Li, Y., Lin, J. K., Lipshultz, S. E., London, S., Lozano, R., Lu, Y., Mak, J., Malekzadeh, R., Mallinger, L., Marcenes, W., March, L., Marks, R., Martin, R., McGale, P., McGrath, J., Mehta, S., Memish, Z. A., Mensah, G. A., Merriman, T. R., Micha, R., Michaud, C., Mishra, V., Hanafiah, K. M., Mokdad, A. A., Morawska, L., Mozaffarian, D., Murphy, T., Naghavi, M., Neal, B., Nelson, P. K., Nolla, J. M., Norman, R., Olives, C., Omer, S. B., Orchard, J., Osborne, R., Ostro, B., Page, A., Pandey, K. D., Parry, C. D. H., Passmore, E., Patra, J., Pearce, N., Pelizzari, P. M., Petzold, M., Phillips, M. R., Pope, D., Pope Iii, C. A., Powles, J., Rao, M., Razavi, H., Rehfuess, E. A., Rehm, J. T., Ritz, B., Rivara, F. P., Roberts, T., Robinson, C., Rodriguez-Portales, J. A., Romieu, I., Room, R., Rosenfeld, L. C., Roy, A., Rushton, L., Salomon, J. A., Sampson, U., SanchezRiera, L., Sanman, E., Sapkota, A., Seedat, S., Shi, P., Shield, K., Shivakoti, R., Singh, G. M., Sleet, D. A., Smith, E., Smith, K. R., Stapelberg, N. J. C., Steenland, K., Stöckl, H., Stovner, L. J., Straif, K., Straney, L., Thurston, G. D., Tran, J. H., Van Dingenen, R., van Donkelaar, A., Veerman, J. L., Vijayakumar, L., Weintraub, R., Weissman, M. M., White, R. A., Whiteford, H., Wiersma, S. T., Wilkinson, J. D., Williams, H. C., Williams, W., Wilson, N., Woolf, A. D., Yip, P., Zielinski, J. M., Lopez, A. D., Murray, C. J. L., and Ezzati, M.: A comparative risk assessment of burden of disease and injury attributable to 67 risk factors and risk factor clusters in 21 regions, 1990-2010: a systematic analysis for the Global Burden of Disease Study 2010, The Lancet, 380, 2224-2260, doi:10.1016/S0140-6736(12)61766-8, 2012.

Lin, Y.-H., Zhang, Z., Docherty, K. S., Zhang, H., Budisulistiorini, S. H., Rubitschun, C. L., Shaw, S. L., Knipping, E. M., Edgerton, E. S., Kleindienst, T. E., Gold, A., and Surratt, J. D.: Isoprene Epoxydiols as Precursors to Secondary Organic Aerosol Formation: Acid-Catalyzed Reactive Uptake Studies with Authentic Compounds, Environ. Sci. Technol., 46, 250258, doi:10.1021/es202554c, 2012.

Lin, Y.-H., Knipping, E. M., Edgerton, E. S., Shaw, S. L., and Surratt, J. D.: Investigating the influences of $\mathrm{SO}_{2}$ and $\mathrm{NH}_{3}$ levels on isoprene-derived secondary organic aerosol formation using conditional sampling approaches, Atmos. Chem. Phys., 13, 84578470, doi:10.5194/acp-13-8457-2013, 2013a.

Lin, Y.-H., Zhang, H., Pye, H. O. T., Zhang, Z., Marth, W. J., Park, S., Arashiro, M., Cui, T., Budisulistiorini, S. H., Sexton, K. G., Vizuete, W., Xie, Y., Luecken, D. J., Piletic, I. R., Edney, E. O., Bartolotti, L. J., Gold, A., and Surratt, J. D.: Epoxide as a precursor to secondary organic aerosol formation from isoprene photooxidation in the presence of nitrogen oxides, P. Natl. Acad. Sci. USA, 110, 6718-6723, doi:10.1073/pnas.1221150110, 2013b.

Lin, Y.-H., Arashiro, M., Martin, E., Chen, Y., Zhang, Z., Sexton, K. G., Gold, A., Jaspers, I., Fry, R. C., and Surratt, J. D.: IsopreneDerived Secondary Organic Aerosol Induces the Expression of Oxidative Stress Response Genes in Human Lung Cells, Environ. Sci. Technol. Lett., 3, 250-254, doi:10.1021/acs.estlett.6b00151, 2016.

Liu, J., D’Ambro, E. L., Lee, B. H., Lopez-Hilfiker, F. D., Zaveri, R. A., Rivera-Rios, J. C., Keutsch, F. N., Iyer, S., Kurten, T., Zhang, Z., Gold, A., Surratt, J. D., Shilling, J. E., and Thornton, J. A.: Efficient Isoprene Secondary Organic Aerosol Formation from a Non-IEPOX Pathway, Environ. Sci. Technol., 50, 9872-9880, 2016.
Livak, K. J. and Schmittgen, T. D.: Analysis of Relative Gene Expression Data Using Real-Time Quantitative PCR and the 2- $\Delta \Delta \mathrm{CT}$ Method, Methods, 25, 402-408, doi:10.1006/meth.2001.1262, 2001.

Nguyen, T. B., Bates, K. H., Crounse, J. D., Schwantes, R. H., Zhang, X., Kjaergaard, H. G., Surratt, J. D., Lin, P., Laskin, A., and Seinfeld, J. H.: Mechanism of the hydroxyl radical oxidation of methacryloyl peroxynitrate (MPAN) and its pathway toward secondary organic aerosol formation in the atmosphere, Phys. Chem. Chem. Phys., 17, 17914-17926, 2015.

Nocker, R. E. T., Schoonbrood, D. F. M., vandeGraaf, E. A., Hack, C. E., Lutter, R., Jansen, H. M., and Out, T. A.: Interleukin- 8 in airway inflammation in patients with asthma and chronic obstructive pulmonary disease, Int. Arch. Allergy Imm., 109, 183191, 1996.

Paulot, F., Crounse, J. D., Kjaergaard, H. G., Kuerten, A., St Clair, J. M., Seinfeld, J. H., and Wennberg, P. O.: Unexpected Epoxide Formation in the Gas-Phase Photooxidation of Isoprene, Science, 325, 730-733, doi:10.1126/science.1172910, 2009.

Paur, H.-R., Cassee, F. R., Teeguarden, J., Fissan, H., Diabate, S., Aufderheide, M., Kreyling, W. G., Hänninen, O., Kasper, G., Riediker, M., Rothen-Rutishauser, B., and Schmid, O.: In-vitro cell exposure studies for the assessment of nanoparticle toxicity in the lung - A dialog between aerosol science and biology, J. Aerosol Sci., 42, 668-692, doi:10.1016/j.jaerosci.2011.06.005, 2011.

Peng, H., Chen, P., Cai, Y., Chen, Y., Wu, Q.-H., Li, Y., Zhou, R., and Fang, X.: Endothelin-1 increases expression of cyclooxygenase- 2 and production of interlukin- 8 in hunan pulmonary epithelial cells, Peptides, 29, 419-424, doi:10.1016/j.peptides.2007.11.015, 2008.

Pye, H. O. T., Pinder, R. W., Piletic, I. R., Xie, Y., Capps, S. L., Lin, Y.-H., Surratt, J. D., Zhang, Z., Gold, A., Luecken, D. J., Hutzell, W. T., Jaoui, M., Offenberg, J. H., Kleindienst, T. E., Lewandowski, M., and Edney, E. O.: Epoxide Pathways Improve Model Predictions of Isoprene Markers and Reveal Key Role of Acidity in Aerosol Formation, Environ. Sci. Technol., 47, 11056-11064, doi:10.1021/es402106h, 2013.

Rager, J. E., Lichtveld, K., Ebersviller, S., Smeester, L., Jaspers, I., Sexton, K. G., and Fry, R. C.: A Toxicogenomic Comparison of Primary and Photochemically Altered Air Pollutant Mixtures, Environ. Health Persp., 119, 1583-1589, doi:10.1289/ehp.1003323, 2011.

Rattanavaraha, W., Chu, K., Budisulistiorini, S. H., Riva, M., Lin, Y.-H., Edgerton, E. S., Baumann, K., Shaw, S. L., Guo, H., King, L., Weber, R. J., Neff, M. E., Stone, E. A., Offenberg, J. H., Zhang, Z., Gold, A., and Surratt, J. D.: Assessing the impact of anthropogenic pollution on isoprene-derived secondary organic aerosol formation in $\mathrm{PM}_{2.5}$ collected from the Birmingham, Alabama, ground site during the 2013 Southern Oxidant and Aerosol Study, Atmos. Chem. Phys., 16, 4897-4914, doi:10.5194/acp-16-4897-2016, 2016.

Reddel, R. R., Ke, Y., Gerwin, B. I., McMenamin, M. G., Lechner, J. F., Su, R. T., Brash, D. E., Park, J.-B., Rhim, J. S., and Harris, C. C.: Transformation of Human Bronchial Epithelial Cells by Infection with SV40 or Adenovirus-12 SV40 Hybrid Virus, or Transfection via Strontium Phosphate Coprecipitation with a Plasmid Containing SV40 Early Region Genes, Cancer Res., 48, 1904-1909, 1988. 
Reuter, S., Gupta, S. C., Chaturvedi, M. M., and Aggarwal, B. B.: Oxidative stress, inflammation, and cancer: How are they linked?, Free Radical Bio. Med., 49, 1603-1616, doi:10.1016/j.freeradbiomed.2010.09.006, 2010.

Riedel, T. P., Lin, Y.-H., Budisulistiorini, S. H., Gaston, C. J., Thornton, J. A., Zhang, Z., Vizuete, W., Gold, A., and Surratt, J. D.: Heterogeneous Reactions of Isoprene-Derived Epoxides: Reaction Probabilities and Molar Secondary Organic Aerosol Yield Estimates, Environ. Sci. Technol. Lett., 2, 38-42, doi:10.1021/ez500406f, 2015.

Riedel, T. P., Lin, Y.-H., Zhang, Z., Chu, K., Thornton, J. A., Vizuete, W., Gold, A., and Surratt, J. D.: Constraining condensed-phase formation kinetics of secondary organic aerosol components from isoprene epoxydiols, Atmos. Chem. Phys., 16, 1245-1254, doi:10.5194/acp-16-1245-2016, 2016.

Riva, M., Budisulistiorini, S. H., Chen, Y., Zhang, Z., D’Ambro, E. L., Zhang, X., Gold, A., Turpin, B. J., Thornton, J. A., Canagaratna, M. R., and Surratt, J. D.: Chemical Characterization of Secondary Organic Aerosol from Oxidation of Isoprene Hydroxyhydroperoxides, Environ. Sci. Technol., 50, 9889-9899, 2016.

Rohr, A. C.: The health significance of gas- and particle-phase terpene oxidation products: A review, Environ. Int., 60, 145-162, doi:10.1016/j.envint.2013.08.002, 2013.

Rohr, A. C., Shore, S. A., and Spengler, J. D.: Repeated exposure to isoprene oxidation products causes enhanced respiratory tract effects in multiple murine strains, Inhal. Toxicol., 15, 1191-1207, doi:10.1080/08958370390229870, 2003.

Samet, J. M., Dominici, F., Curriero, F. C., Coursac, I., and Zeger, S. L.: Fine particulate air pollution and mortality in 20 US Cities, 1987-1994, New England Journal of Medicine, 343, 1742-1749, doi:10.1056/NEJM200012143432401, 2000.

Schreck, R., Albermann, K., and Baeuerle, P. A.: Nuclear Factor $\mathrm{Kb}$ : An Oxidative Stress-Responsive Transcription Factor of Eukaryotic Cells (A Review), Free Radical Res. Comm., 17, 221237, doi:10.3109/10715769209079515, 1992.

Schwartz, J., Slater, D., Larson, T. V., Pierson, W. E., and Koenig, J. Q.: Particulate Air-Pollution and Hospital Emergency Room Visits for Asthma in Seattle, Am. Rev. Respir. Dis., 147, 826$831,1993$.

Seagrave, J.: Mechanisms and implications of air pollution particle associations with chemokines, Toxicol. Appl. Pharm., 232, 469477, doi:10.1016/j.taap.2008.08.001, 2008.

Sies, H.: Oxidants And Antioxidants: Pathophysiologic Determinants and Therapeutic AgentsOxidative stress: From basic research to clinical application, Am. J. Med., 91, S31-S38, doi:10.1016/0002-9343(91)90281-2, 1991.

Surratt, J. D., Murphy, S. M., Kroll, J. H., Ng, N. L., Hildebrandt, L., Sorooshian, A., Szmigielski, R., Vermeylen, R., Maenhaut, W., and Claeys, M.: Chemical composition of secondary organic aerosol formed from the photooxidation of isoprene, J. Phys. Chem. A, 110, 9665-9690, 2006.
Surratt, J. D., Kroll, J. H., Kleindienst, T. E., Edney, E. O., Claeys, M., Sorooshian, A., Ng, N. L., Offenberg, J. H., Lewandowski, M., Jaoui, M., Flagan, R. C., and Seinfeld, J. H.: Evidence for organosulfates in secondary organic aerosol, Environ. Sci. Technol., 41, 517-527, doi:10.1021/es062081q, 2007.

Surratt, J. D., Chan, A. W. H., Eddingsaas, N. C., Chan, M., Loza, C. L., Kwan, A. J., Hersey, S. P., Flagan, R. C., Wennberg, P. O., and Seinfeld, J. H.: Reactive intermediates revealed in secondary organic aerosol formation from isoprene, P. Natl. Acad Sci. USA, 107, 6640-6645, doi:10.1073/pnas.0911114107, 2010.

Tao, F., Gonzalez-Flecha, B., and Kobzik, L.: Reactive oxygen species in pulmonary inflammation by ambient particulates, Free Radical Bio. Med., 35, 327-340, doi:10.1016/S08915849(03)00280-6, 2003.

Uchida, K.: A Lipid-derived Endogenous Inducer of COX-2: a Bridge Between Inflammation and Oxidative Stress, Mol. Cells, 25, 347-351, 2008.

Volckens, J., Dailey, L., Walters, G., and Devlin, R. B.: Direct Particle-to-Cell Deposition of Coarse Ambient Particulate Matter Increases the Production of Inflammatory Mediators from Cultured Human Airway Epithelial Cells, Environ. Sci. Technol., 43, 4595-4599, doi:10.1021/es900698a, 2009.

Xu, L., Guo, H. Y., Boyd, C. M., Klein, M., Bougiatioti, A., Cerully, K. M., Hite, J. R., Isaacman-VanWertz, G., Kreisberg, N. M., Knote, C., Olson, K., Koss, A., Goldstein, A. H., Hering, S. V., de Gouw, J., Baumann, K., Lee, S. H., Nenes, A., Weber, R. J., and $\mathrm{Ng}, \mathrm{N}$. L.: Effects of anthropogenic emissions on aerosol formation from isoprene and monoterpenes in the southeastern United States, P. Natl. Acad. Sci. USA, 112, 37-42, doi:10.1073/pnas.1417609112, 2015.

Yan, Z., Wang, J., Li, J., Jiang, N., Zhang, R., Yang, W., Yao, W., and $\mathrm{Wu}, \mathrm{W} .:$ Oxidative stress and endocytosis are involved in upregulation of interleukin-8 expression in airway cells exposed to $\mathrm{PM}_{2.5}$, Environ. Toxicol., doi:10.1002/tox.22188, online first, 2015.

Zavala, J., Lichtveld, K., Ebersviller, S., Carson, J. L., Walters, G. W., Jaspers, I., Jeffries, H. E., Sexton, K. G., and Vizuete, W.: The Gillings Sampler - An electrostatic air sampler as an alternative method for aerosol in vitro exposure studies, Chem.-Biol Interact., 220, 158-168, doi:10.1016/j.cbi.2014.06.026, 2014.

Zhang, Z., Lin, Y.-H., Zhang, H., Surratt, J. D., Ball, L. M., and Gold, A.: Technical Note: Synthesis of isoprene atmospheric oxidation products: isomeric epoxydiols and the rearrangement products cis- and trans-3-methyl-3,4-dihydroxytetrahydrofuran, Atmos. Chem. Phys., 12, 8529-8535, doi:10.5194/acp-12-85292012, 2012. 